ORIGINAL ARTICLE

\section{Human Papilomavirus Genotype Distribution in Women From Montenegro}

\begin{abstract}
Introduction. The distribution of HPV genotypes in women can aid in the selection of an appropriate screening test for detection of HPV infection. For example, identification of particular HPV genotypes strains may reveal patients at high-risk. The purpose of this study was to determine the range and frequency of HPV genotypes in women in Montenegro.

Methods. Cervical smears were taken at the Gynecological Department of the Clinical Center in Podgorica from women with clinical signs of HPV infection. HPV genotypes were determined using PCR amplification and enzyme restriction. PCR products were amplified with group-specific primers MY09/MY11 and restricted with seven different endonucleases. Patterns of restriction fragment length polymorphism (RFLP) were compared to predefined standard patterns.

Results. We tested a total of 189 women and found HPV infection in 1/5 of them (20\%). Among those infected (38 HPV DNA positive women), there were 16 different HPV genotypes. Genotyping of this group showed that a third of them had HPV genotype 16. The second most frequent HPV infection was with HPV genotype 58, found in $10 \%$ of participants.

Conclusion. From the results of our research, we believe that detection and identification of the broader spectrum of high-risk HPV genotypes will help to identify women who are likely to develop cervical cancer.
\end{abstract}

\section{KEY WORDS}

cervical cancer, HPV genotype; HPV infection; PCR

DOI: $10.7251 / S M D 1201011 V$

(Scr Med 2012;43:11-4)

\section{Danijela Vujošević, Vineta Vuksanović, ${ }^{1,2}$}

${ }^{1}$ Center for Medical Microbiology, Institute of Public Health, Podgorica, Montenegro

${ }^{2}$ Medical faculty, University of Montenegro, Podgorica, Montenegro

\section{Correspondence}

Dr Danijela Vujošević, Center for Medical Microbiology, Institute of Public Health, Džona Džeksona bb 810oo, Podgorica, Montenegro

Phone: +38267626181

E-mail: danijela.vujosevic@ijzcg.me

Submitted: January 29, 2012

Accepted: April 25, 2011
Cervical cancer is the second most common cancer in women worldwide. This type of cancer evolves from noninvasive intraepithelial stages, cervical intraepithelial neoplasia (CIN) grade 2 and 3, to invasive cancer. Infections with certain types of the carcinogenic human papilloma virus (HPV) have the highest risk of progressing CIN to cancer. $^{1,2}$

More than 100 different HPV genotypes have been identified, and of these, approximately 45 genotypes were detected in anogenital region. ${ }^{3}$ The potentially high-risk HPV genotypes include: 16, 18, 31, 33, 35, 39, 45, 51, 52, $56,58,59$, as defined by their prevalence in the CIN lesions and cervical cancers. ${ }^{4,5}$ Perhaps, there are also potentially high-risk types $(26,53,66,68,73$ and 82$)$ as well. ${ }^{4,5}$ According to most investigators, cervical cancer occurs in women who had been previously infected with the so-called high-risk HPV genotypes; the prevalence of
HPV infection in women with invasive form of cervical cancer is $99.7 \% .^{6,7}$

Because HPV cannot be cultured in vitro, and serological tests are ineffective, detection of the infection requires molecular methods. ${ }^{8}$ The polymerase chain reaction (PCR) is the most sensitive and the most commonly used method for the detection of HPV infection and HPV genotyping.9,10 Accordingly, we used HPV genotyping based on enzyme restriction of PCR products of products from restriction (restriction fragment length polymorphism (RFLP). ${ }^{11}$

Numerous studies have established that the distribution of HPV genotypes differs with various geographical areas. The main objective of our study was to determine the range and frequency of HPV genotypes in women from Montenegro. 


\begin{abstract}
Methods
Cervical smears were taken from 189 patients with clinical signs of HPV infection (cervicitis chronica, erosio vera cervicis, erythroplakia portio vaginalis uteri, leukoplakia, tumor cervicitis). The samples were collected at the Clinical Center in Podgorica during 2005-2006, and HPV infection was established with a commercial diagnostic kit HC II (Digene Specimen Collection Kit, Silver Spring, Maryland, USA) at the Laboratory for Molecular Microbiology and Diagnostics of AIDS, Institute of Microbiology and Immunology, Faculty of Medicine in Ljubljana. The method involves detection of DNA HPV in cervical materials and amplification by PCR. DNA from cervical samples was isolated by a procedure previously developed in that laboratory (12). For the first phase of PCR diagnostics, HPV DNA amplification, we used two group-specific primers, MYo9 and MY11. These two primers allow amplification of a 450 bp conservative fragment of the HPV L1 gene. By using these primers we could identify more than 50 different HPV genotypes in a single PCR reaction. Specificity of PCR products (amplicons) was then determined by gel-electrophoresis as previously described (13).
\end{abstract}

HPV genotyping was established in HPV positive samples by enzyme restriction of PCR products and identification of these by RFLP. Forty-four different restriction patterns of MYo9/MY11 PCR products have been described, each specific for a particular HPV genotype. RFLP used seven different restriction endonucleases: BamHI, DdeI, HaeIII, DNA HinfI digest, PstI, RsaI and Sau3AI (Gibco-BRL, Bethesda, USA). Patterns of enzyme restriction of PCR products were then compared to predefined standard patterns of restriction to define the genotype (13).

\section{Results}

Out of 189 women included in our examined cohort, most (79\%) were between ages of 20 to 45 years. These women

\section{Table 1}

Distribution of HPV genotypes in 38 HPV infected women

\begin{tabular}{lll}
\hline HPV genotype & $\begin{array}{l}\text { No. of } \\
\text { women }\end{array}$ & $\begin{array}{l}\text { Percent of } \\
\text { women }\end{array}$ \\
\hline 6 & 3 & 7.9 \\
\hline 16 & 14 & 36.8 \\
\hline 31 & 3 & 7.9 \\
\hline 58 & 4 & 10.5 \\
\hline
\end{tabular}

$33,51,52,54,61,66, \mathrm{MM}_{7}$ $6+\mathrm{M} 109+58,16+6,16+52$, $16+\mathrm{CP} 8304,18+53,26+\mathrm{X}^{*}$, 1 each 2.6 $58+52$

\begin{tabular}{lll}
\hline Total & 38 & 100 \\
\hline
\end{tabular}

*Undefined HPV genotype were thus fully mature and likely to be sexually active. The average age of participants was 38 years; the youngest was 23 and the oldest was 68 years old.

HPV infection was found in 38 women out of the total 189 examined participants (20\%). Genotyping of the HPV from these 38 infected women showed that the HPV genotype 16 was present in more than a third of the participants (Table 1). Among the HPV infected women, 31 of them had a single dominant HPV type (Table 1). Six of the 38 infected individuals had two different HPV genotypes.

In our analysis of 16 detected HPV genotypes, we confirmed that 31 out of 38 patients, or more than $80 \%$, had high-risk HPV genotypes. Among the remaining infected individuals, samples from two women had genotypes that were probably high-risk, whereas five others had low-risk HPV genotypes. We noted that out of 38 HPV DNA positive participants, the infection was most common in women aged 20-30 years (25/38). Ages in the older group (13/38) ranged 40-50 years. Seven women, aged 25 to 30 years, had multiple infections (Table 2). These included both high-risk and probably potentially high-risk HPV genotypes.

Table 2. Multiple HPV infections by age group of participants

\begin{tabular}{lll}
$\begin{array}{l}\text { HPV genotypes } \\
\text { in multiple HPV } \\
\text { infections }\end{array}$ & $\begin{array}{l}\text { No. of } \\
\text { samples }\end{array}$ & $\begin{array}{l}\text { Age distribution } \\
\mathbf{2 5 - 3 0} \text { year }\end{array}$ \\
\hline $6+\mathrm{M} 109+58$ & 1 & 26 years \\
\hline $16+6$ & 1 & 26 years \\
\hline $16+52$ & 1 & 26 years \\
\hline $16+\mathrm{CP} 8304$ & 1 & 26 years \\
\hline $18+53$ & 1 & 26 years \\
\hline $26+\mathrm{X}^{*}$ & 1 & 27 years \\
\hline $58+52$ & 1 & 27 years \\
\hline Total & 7 & - \\
\hline
\end{tabular}

\section{Discussion}

Half the patients in our study were infected with two HPV genotypes, 16 and 58 . These findings indicate the need for a broader study of HPV infection and genotyping. The fact that meta-analysis of data published from 1995 to 2009 in $1,016.719$ women showed that only five types of HPV (16, $18,31,52$ and 58 ) are most frequent genotypes ${ }^{14}$ should stimulate further studies of our Montenegrin population.

Detection of HPV DNA is useful for triage of patients who have abnormal PAP test of cervical smears (15). Early detection of HPV, followed by treatment of cervical dysplasia, can significantly reduce the risk of developing cervical cancer (16). In this regard, accurate detection of HPV infection is 
clinically important and requires a reliable diagnostic method. Sensitive detection of HPV and accurate genotyping are crucial. Determination of HPV genotypes in patients is thus especially important for detection of the persistence of infection as well as for prevention of cervical cancer.

Additionally, information on the distribution of HPV genotypes in women in a particular country can instigate appropriate epidemiological monitoring of HPV genotype distribution in that country. Such information can facilitate application of vaccines effective against HPV. Studies show that HPV genotype 16 is the most prevalent (50-65\%) in cervical cancer, while HPV genotype 18 occurs in $7-20 \%$ $(4,17,18)$. Given that HPV infection was diagnosed in $20 \%$ of the women enrolled in our study, the need for early and accurate detection of HPV infection seems apparent.

Epidemiology of HPV infection is a dynamic process; HPV infection can be acquired and eliminated over time. Hypothetically, the viruses can persist at very low levels and remain undiagnosed. Development of cervical lesions is likely associated with persistent HPV infection. Weakened immunity may also play a role, causing a rise in viral load, which, in turn, can result in multiple HPV infections. This hypothesis is supported by the observation that HIVinfected women with severely compromised immune systems have a prevalence of multiple HPV genotypes (20).

We noted that HPV infections are more common in younger women than older ones. It is assumed that infection in this group increases as a result of an insufficient immune response to HPV infection. We also find that multiple HPV infection (more than one HPV genotype) occurred more frequently in younger women and showed at least one highrisk or probably high-risk HPV genotype. Because young women with HPV infection are more likely to experience cofactor events (births, sexually transmitted diseases, etc.) that promote occurrence of cervical carcinoma, the need for HPV screening and typing seems obvious.

The combination of cytology and HPV testing is highly predictive for future CIN2+ disease and thus can be used to screen a presumed healthy population. ${ }^{2}$ Our screening program, based only on detection of HPV 16 and HPV 18 for women in Montenegro, would be insufficient for identifying those individuals most likely to develop cervical cancer. In order to detect all high-risk HPV genotypes, the methodology should be expanded to include even minor components and used along with cervical cytology to improve screening results. Identification of specific protein biomarkers (e.g., those are involved in cell cycle regulation, signal transduction, DNA replication, and cellular proliferation) may help to detect women at greatest risk for developing cervical cancer. Use of such biomarkers in both cervical cytology and histology could significantly improve cervical screening by reducing false-negative and falsepositive results.

\section{Author contributions}

Both authors jointly developed the study aims, design and analysis protocol. DV obtained the data and wrote the first draft of the paper. Both authors contributed to the final version of the manuscript.

\section{Conflicts of interest}

No potential conflicts of interest relevant to this article was reported.

\section{Acknowledgements}

The authors thank to Professor Mario Poljak, Head of Laboratory for Molecular Microbiology and Slovenian HIV/AIDS Reference Centre at the Institute of Microbiology and Immunology, Faculty of Medicine, Ljubljana, in whose laboratory molecular part of the research was completed.

\section{References}

1. zur Hausen, H. Papillomaviruses in the causation of human cancers - a brief historical account. Virology 2009;384:260-5.

2. Wentzensen N, Walker J, Schiffman M, et al. Heterogeneity of high grade cervical intraepithelial neoplasia related to HPV16: Implications for natural history and management, Int J Cancer 2012 [Epub ahead of print]

3. De Villiers EM, Fauquet C, Broker TR, Bernard HU, zur Hausen H. Classification of papillomaviruses. Virology 2004; 324:17-27.

4. Li N, Franceschi S, Howell-Jones R, Snijders PJ, Clifford GM. Human papillomavirus type distribution in 30,848 invasive cervical cancers worldwide: Variation by geographical region, histological type and year of publication. Int J Cancer 2011;128: 927-35

5. Muńoz N, Bosch FX, de Sanjose S, et al. Epidemiologic classification of human papillomavirus types associated with cervical cancer. N Engl J Med 2003; 348: 518-27.

6. Stoler MH. Human papillomaviruses and cervical neoplasia: a model for carcinogenesis. Int J Gynecol Pathol 2000; 19: 16-28.

7. Bulkmans NW, Berkhof J, Rozendaal L, et al. Human papillomavirus DNA testing for the detection of cervical intraepithelial neoplasia grade 3 and cancer: 5-year follow-up of a randomized controlled implementation trial. Lancet 2007;370:1764-72.

8. Brink AA, Snijders PJ, Meijer CJ. HPV detection methods. Dis. Markers 2007; 23:273-81.

9. Molijn A, Kleter B, Quint W, et al. Molecular diagnosis of human papillomavirus (HPV) infections. J Clin Virol 2005;32:S43-S51.

10. Poljak M, Avšić-Županc T, Seme K. Verižna reakcija s polmerazo - nova raziskovalna in diagnostična metoda v virologiji. Med Razgl 1994; 33:379-400.

11. Poljak M, Seme K, Koren S. The polymerase chain reaction: a critical review of its uses and limitations in diagnostic microbiology. Period Biol 1996; 98:183-90.

12. Poljak M, Brenčić A, Seme K, Vince A, Marin IJ. Comparative evaluation of the first and second generation Digene Hybrid Capture assays for detection of human papillomaviruses associated with high or intermediate risk for cervical cancer. J Clin Microbiol 1999; 37:796-7.

13. Poljak M, Seme K, Gale N. Detection of human papillomaviruses in tissue specimens. Adv Anatomic Pathol 1998;5:216-34. 
14. Cox, J. T. History of the use of HPV testing in cervical screening and in the management of abnormal cervical screening results.

J. Clin. Virol. 2009;45:S3-S12

15. Bernard HU, Chan SY, Manos MM. Identification and assessment of known and novel human papilomaviruses by polymerase chain reaction amplification, restriction fragment lenth polymorphism, nucleotide sequence, and phylogenetic algorithms. J Infect Dis 1994;170: 1077-85.

16. Wright Jr TC, Massad S, Dunton CJ, et al. 2006 consensus guidelines for the management of women with abnormal cervical screening tests. J Low Genit Tract Dis 2007;11:201-22.

17. Smith JS, Lindsay L, Hoots B, et al. Human papillomavirus type distribution in invasive cervical cancer and high-grade cervical lesions: a meta-analyses update. Int J Cancer 2007; 121:621-32.
18. Munoz N, Castellsaque X, Gonzales AB, Gissman L. HPV in the etiology of human cancer. Vaccin 2006; 24:S3:1-10.

19. Bruni L, Diaz M, Castellsagué X, Ferrer E, F. Xavier Bosch, de Sanjose S. Cervical Human Papillomavirus Prevalence in 5 Continents: Meta-Analysis of 1 Million Women with Normal Cytological Findings. J Infect Dis 2010;202: 1789-99.

20. Levi JE, Kleter B, Quint WGV, et al. High prevalence of human papillomavirus (HPV) infections and high frequency of multiple HPV genotypes in human immunodeficiency virus-infected women in Brazil. J Clin Microbiol 2002; 40: 3341-5.

\section{Distribucija genotipova humanih papiloma virusa kod žena u Crnoj Gori}

\section{Danijela Vujošević, Vineta Vuksanović}

\section{APSTRAKT}

Uvod. Distribucija HPV genotipova kod žena je važna za izbor odgovarajućeg skrining testa za dokazivanje infekcije sa HPV. U tom smislu je i cilj istraživanja bio utvrditi dijapazon i učestalost genotipova HPV koji su prisutni kod ispitivanih žena u Crnoj Gori. Metode. U istraživanje je uključeno 189 ispitanica kojima su uzeti brisevi grlića materice koji su imali kliničke znake, pri ginekološkom pregledu u Kliničkom centru u Podgorici. Genotipove HPV smo odredili metodom enzimske razgradnje PCR produkata dobijenih amplifikacijom sa grupno-specifičnim početnim oligonukleotidima MY09/MY11, razgrađenih sa sedam restrikcijskih enzima.

Rezultati. Od ukupnog broja žena kod $1 / 5$ ispitanica (20\%, 38/189) dokazano je prisustvo HPV infekcije. Ustanovili smo prisustvo ukupno 16 različitih genotipova HPV. Genotipizacija rađena kod 38 DNK HPV pozitivnih žena pokazuje da je dominantan genotip HPV genotip 16 (36.8\%, 14/189). Na drugo mjesto po učestalosti je infekcija sa HPV 58 prisutna kod 10.5\% ispitanica.

Zaključak. S obzirom na rezultate našeg istraživanja, mišljenja smo da pri aktivnom traženju žena, kod kojih postoji veća vjerovatnoća za razvoj karcinoma grlića materice, potrebno uraditi testove koji detektuju širi spektar visokorizičnih HPV genotipova.

\section{KLJUČNE RIJEČI}

HPV genotip; HPV infekcija; karcinom cerviksa; PCR 